\title{
SEXUALLY TRANSMITTED INFECTIONS - PREVALENCE, KNOWLEDGE AND BEHAVIOURS AMONG PROFESSIONAL DEFENCE FORCES IN ESTONIA: A PILOT STUDY
}

\author{
R David Parker ${ }^{1}$, Kristi Rüütel ${ }^{2}$ \\ ${ }^{1}$ School of Public Health, West Virginia University, Morgantown, WV, USA \\ ${ }^{2}$ Infectious Diseases and Drug Abuse Prevention Department, Estonian National Institute for Health Development, Tallinn, Estonia
}

\section{SUMMARY}

Objectives: Our study assessed sexually transmitted infections (STI) occurrence and risk behaviours from a sample of the defence forces of Estonia. Previous research on military personnel yields various results on the prevalence of STIs and high risk behaviours. The increasing recognition of high risk behaviours among military personnel is evident given increased programmes that focus on education of drug use and risky sexual behaviours. Many militaries conduct routine, periodic screening for diseases such as HIV and viral hepatitis at entry and pre-foreign deployment. Protecting deployed forces from secondary infections is important as persons with chronic viral infections are living longer, healthier lives and are more frequently serving in military forces.

Methods: A cross sectional study used convenient sampling among professional defence forces. Participation was both voluntary and anonymous.

Results: Of 186 participants accounting for $7.3 \%$ of all forces ( $86.6 \%$ male, mean age 30 years) at selected bases, there were four cases of chlamydia. No cases of gonorrhea, trichomoniasis, hepatitis C, hepatitis B, or HIV were found. One person reported ever injecting drugs.

Conclusions: These findings indicate a lower STI occurrence among professional defence forces in Estonia compared with the non-military population. While these rates were lower than expected, as a voluntary study, people suspicious of having an STI might opt not to participate, limiting generalizability to the remainder of the military. Militaries without regular screening programmes could consider regular scheduled testing for STIs, HIV and blood borne pathogens, even if voluntary, especially prior to foreign deployment. Consistent testing would align across many militaries who deploy international peace keepers.

Key words: military, defence forces, risk behaviour, screening, sexually transmitted infections

Address for correspondence: R. D. Parker, School of Public Health, West Virginia University, HSC North, G103C, PO Box 9127, Morgantown, WV, 26506 United States. E-mail: rdparker@hsc.wvu.edu

https://doi.org/10.21101/cejph.a4498

\section{INTRODUCTION}

Previous research on military personnel has concluded with various results, identifying sexually transmitted infections (STIs) and high risk behaviours as both higher and lower than in the general population $(1,2)$. Knowing the prevalence of blood borne pathogens, including STIs and viral hepatitis, is important for a military to ensure its members receive proper education, care and training (3-7). At one time, the primary concern in testing military forces was to prevent infections in combat situations when there was a potential for blood exposure. Chronic, long term viral infections, including human immunodeficiency virus (HIV) and hepatitis $\mathrm{C}$ virus (HCV) may now be effectively managed once diagnosed. The increased life expectancy of infected persons can equal that of uninfected persons (8). Persons with chronic viral infections are growing in numbers and due to advancing treatment are now able to serve in military forces compared to the recent past. Defence forces need to be deployment ready at all times, whether on assignments that are domestic, humanitarian, security, defensive, or peace keeping (9). Part of this readiness is ensuring appropriate training, prophylaxis, vaccinations, and other preventive safeguards for personnel deployed to regions with vector borne infectious diseases, such as yellow fever and most recently ebola. Depending on health status, some personnel may have different deployment availability given the status of chronic infections.

One component of understanding an approach to testing in a military population is through identifying risk behaviours; alcohol and other drug use as well as high sexual risk behaviours help identify persons at increased risk of disease acquisition (10-13). As drug use and high risk sexual behaviour are driving forces for these infections, targeted education and prevention programmes that include testing can be provided to personnel when risk behaviours are known to be prevalent. Globally, alcohol prevention programmes are emerging in militaries, indicating the readiness of defence ministries to provide necessary education and training to improve the health of its personnel (14).

In many countries, including nations with high prevalence rates, there are no formal studies on STIs, blood borne pathogens, 
or risk behaviours in militaries. In these same nations, while prevalence data are collected from persons known to engage in high risk behaviours, such as injecting drug users, commercial sex workers or men who have sex with men, but less frequently, military personnel. In Estonia, a nation in Eastern Europe with a high prevalence of HIV and HCV as well as persons who inject drugs, military data are limited, while data on knowledge and risk behaviours among Estonian youth aged 10-29 have been collected in studies conducted by the National Institute for Health Development (NIHD). The NIHD has also collected data on HIV knowledge and testing in the general population aged 16-64. (15)

The primary objective of this study is to fill a gap in knowledge and to inform the national government of the prevalence of HIV, hepatitis b virus (HBV), HCV, and STIs among professional defence forces when there is no routine STI or HIV testing programme (Government Order No 282). These findings will provide input to government and defence forces for planning testing programmes in the future. Another goal of the study was to estimate the risk-behaviours, attitudes and knowledge related to STIs to create additional input for planning education and prevention strategies for military forces in the region.

\section{MATERIALS AND METHODS}

A cross sectional study used convenience sampling among professional defence forces. Participation was both voluntary and anonymous. Persons must have been at least 18 years old and able to provide consent. A sample size of 385 participants was planned with proportional recruitment from multiple sites to represent the total military. In choosing the study sites the following issues were taken into consideration: number of military personnel in each base, presence of medical unit, work load of the personnel of the medical unit, and transportation issues of biological samples. Due to Norwalk-virus outbreak during this study, a large site withdrew from participation and a smaller sight was included. Data were collected between March 20 and September 30, 2013. This study was reviewed and approved by the Tallinn Medical Research Ethics Committee (decision number 157, from February 14, 2013).

Study personnel received training prior to data collection and included privacy and confidentiality of the participants. Study information was distributed orally and in a written form. Participants were consented and received study information in their language of choice (Estonian or Russian). Recruitment and biological sample collection were conducted during the regular working hours. Each participant received a unique participant code used to link the questionnaire and biological samples. To determine risk of acquiring STIs among other behaviours, each participant completed a self-guided Knowledge Attitude Behaviour and Perception (KABP) questionnaire. KABP questionnaires are commonly used in research to identify information related to sexual behaviours and stigmas associated with STIs $(16,17)$. The $\mathrm{KABP}$ questionnaire used in this project was a modified version of the assessment administered to conscripts in 2012 (18). The modified version required approximately 20 minutes to complete and included 34 questions on sexual behaviours, drug use, testing for STIs, and knowledge.

Staff instructed participants how to collect urine (from men, 5 $\mathrm{ml}$ ) or vaginal swab (from women) and when to return samples.
Participants were given laboratory supplies to collect urine or vaginal swab and a small reminder card which included participant number and instructions for specimen collection, as well as time and date to return. From every participant $10 \mathrm{ml}$ of venous blood was collected. HBV, HCV and HIV tests used blood while gonorrhoea, chlamydia and trichomoniasis were urine/vaginal swab based tests. Biological samples were analysed in Quattromed HTI Laboratories using the following methods to identify infection markers: HIV antibodies + antigen (HIV 1, $2 \mathrm{Ab}+\mathrm{Ag}$ ); $\mathrm{HCV}$ antibodies (HCV Ab); HBV antigen (HBsAg); chlamydia (C trachomatis DNA); gonorrhoea (N gonorrhoea DNA); and trichomoniasis (T vaginalis DNA). HIV, HCV and HBV test were screening tests, for confirming the diagnosis additional test were required. Tests results were reported to the medical units by web-based system. In case the participants were interested, they were able to receive the results of the tests based on their unique participation code. Receiving test results was voluntary. In case the test results for chlamydia, gonorrhoea or trichomoniasis were positive, participants were offered treatment by the military medical services. In case the test results for HIV, HBV or HCV were positive, participants were offered additional testing, because in the study only screening tests were used and the final diagnosis had to be confirmed. Considering the aims of the study we did not collect any information on how many participants returned for their test results.

Double data entry of the KABP into Microsoft Excel was conducted and the files imported into Stata for comparison. Discrepancies were resolved by referring to the source documentation. In case that the source documentation was not clear, a determination was made by the Principal Investigators on this project with documentation on the method of data clarification. Data were analysed using Stata 10.0.

\section{RESULTS}

186 participants represented $17.7 \%$ of professional defence forces at the selected bases and $7.3 \%$ of the total professional military $(n=2,564)$ at the time of the study. $13.4 \%$ of the participants were female $(n=25)$ and $86.6 \%$ male $(n=161)$. The mean age of the participants was 29.5 years (median 26.5 years, range 19-60 years). 89.7\% were Estonians ( $n=166), 8.1 \%$ were Russians $(n=15)$ and $2.2 \%$ were other nationalities $(n=4$; Lithuanian, German, Finnish, and Ukrainian). Data on socio-demographics, risk behaviours and HIV/STI symptoms and testing by gender is presented in Table 1.

HIV related knowledge and attitudes were assessed with 12 questions. The majority of the participants had positive attitudes towards condom use, correct knowledge of HIV transmission and accepting attitudes towards people with HIV.

Biological samples, including blood and urine or vaginal samples, were suitable for testing from all participants. $28 \mathrm{men}$ reported a suspected STI in the last 12 months, almost one quarter (22.37\%) reported alcohol use prior to last sexual encounter. We identified 4 cases of chlamydia with each case reporting sexual activity in the last 12 months (prevalence rate among sexually active men 2.4) and all men younger than 30-years of age. One reported one sexual partner and three reported two sexual partners in the last 12 months. One of the four had any suspicion of an STI 
Table 1. Socio-demographic and behavioural data $(N=186)$

\begin{tabular}{|c|c|c|c|c|}
\hline & \multicolumn{2}{|c|}{ Male $(n=161)$} & \multicolumn{2}{|c|}{ Female $(n=25)$} \\
\hline & $\mathrm{n}$ & $\%$ & $\mathrm{n}$ & $\%$ \\
\hline Age median in years (range) & \multicolumn{2}{|c|}{$26(19-56)$} & \multicolumn{2}{|c|}{$38(22-60)$} \\
\hline Estonian ethnicity & 149 & 93.10 & 17 & 68.00 \\
\hline \multicolumn{5}{|l|}{ Education } \\
\hline$<$ High school & 7 & 4.40 & 0 & 0.00 \\
\hline High school & 117 & 72.70 & 13 & 52.00 \\
\hline Bachelor's degree & 30 & 18.63 & 11 & 44.00 \\
\hline Graduate degree & 7 & 4.35 & 1 & 4.00 \\
\hline \multicolumn{5}{|l|}{ Sexual behaviour } \\
\hline Ever had sex (anal or vaginal) & 156 & 96.90 & 23 & 92.00 \\
\hline Sex in last 12 months (anal or vaginal) & 148 & 91.93 & 22 & 88.00 \\
\hline Number of sex partners in last 12 months & \multicolumn{2}{|c|}{$2(1-12)^{*}$} & \multicolumn{2}{|c|}{$1(1-4)^{*}$} \\
\hline Alcohol use before last intercourse & 69 & 44.23 & 7 & 30.43 \\
\hline Illegal drugs use before last intercourse & 1 & 0.64 & 0 & 0.00 \\
\hline \multicolumn{5}{|l|}{ STIs and HIV } \\
\hline STI suspicion in last 12 months & 28 & 17.39 & 0 & 0.00 \\
\hline HIV testing ever & 57 & 35.41 & 13 & 52.00 \\
\hline \multicolumn{5}{|l|}{ Result of last HIV test } \\
\hline Negative & 56 & 34.78 & 13 & 52.00 \\
\hline Inconclusive & 1 & 0.62 & 0 & 0.00 \\
\hline \multicolumn{5}{|l|}{ Injection drug use } \\
\hline Ever injected drugs (yes) & 1 & 0.62 & 0 & 0.00 \\
\hline \multicolumn{5}{|l|}{ Other risk factors } \\
\hline Tattooing/piercing (non-professional) & 27 & 16.77 & 5 & 20.00 \\
\hline Blood-transfusion before 1994 & 3 & 1.86 & 1 & 4.00 \\
\hline
\end{tabular}

${ }^{*}$ Median (range)

in the last 12 months. These men were able to access treatment through the military medical unit or the civilian system. No other STIs were discovered.

HIV testing was reported for $16(8.6 \%)$ of participants in the last year included in a total of $77(41.4 \%)$ reporting ever having an HIV test. More than half of the participants (58.6\%) reported never having an HIV test.

\section{DISCUSSION}

The current study assessed markers of prevalence for HIV, STIs, other pathogens, and high risk behaviours among professional defence forces. This was the first study of this kind in the region. The study was conducted to provide baseline data to the military and defence policy makers to aid development of testing and education policy as well as to shed a light on the limited issue of blood borne pathogens in military personnel.

Our results indicate that in general, HIV knowledge among the Estonian professional defence forces is very good. The majority of participants had positive attitudes towards condom use as well as toward people living with HIV. Responses to questions pertaining to HIV transmission were more than $90 \%$ correct. HIV testing rates were comparable to the same age groups in general population with reported illegal drug use less than the general population (19). The prevalence of infections in our study was as expected and comparable to the other countries. As one person in our study reported a lifetime history of injection drugs, the lack of identifying a single case of HIV, HCV and HBV was not surprising (20). While chlamydia is the most common bacterial STI in Europe, prevalence rates as high as $5-10 \%$ have been described among sexually active youth (21).

The study included 186 people from three military bases (comprising $7.3 \%$ of the total professional defence forces at the time of the study). As we used convenience sampling the results of this study cannot be generalized to all military personnel in Estonia. The initial sample size was planned to be 385 , but after an outbreak of Norwalk virus at one base required relocation of the study to another site, there was lower recruitment and the study concluded in September 2013 after almost seven months of recruitment (22). The limitations of our study are convenience sampling and recruitment in only a few military bases. We were not able to use random sampling because we wanted to ensure the confidentiality of the defence forces. Answering questions related to sexual behaviour and illegal drug use may have been prone to recall and desirability bias. It was not possible to collect the very first morning urine from all participants, and this may have influenced the sensitivity 
of the PCR methodology. We did not collect and compare data on the urine sample collection time.

This project demonstrates an overall acceptance of a voluntary study of this nature among military personnel. Given these findings, considerations and study limitations, future research should be conducted on a larger scale to assess actual prevalence rates. Reducing questions pertaining to the knowledge and attitudes, and increasing behavioural data may improve an understanding of behaviours, while reducing the participation time.

Many industrialized nations are tailoring programmes toward their militaries to provide testing, education and risk reduction. Militaries could consider more inclusive testing campaigns, such as voluntary testing in addition to implemented programmes. An example of a common implemented requirement would be testing at entry, prior to deployment, and every two years. Additionally, policies should be developed that would bar discrimination against any service member and ensure equitable treatment.

\section{CONCLUSIONS}

In general, the findings from this study indicate that HIV knowledge among the Estonian professional defence forces is good. Additionally, STIs among Estonian defence forces are lower than that of the general population. However, findings cannot be gerneralized to the entire population of military personnel in Estonia as this study utilized a convenient sample with voluntary participation.

\section{Acknowledgements}

The authors thank the Estonian Defence Forces and Estonian Ministry of Defence for their support and assistance.

\section{Conflict of Interests}

None declared

\section{Funding}

This project was funded by the US Department of Defense HIV/AIDS Prevention Program.

\section{REFERENCES}

1. Harbertson J, Grillo M, Zimulinda E, Murego C, Brodine S, May S, et al. HIV seroprevalence, associated risk behavior, and alcohol use among male Rwanda Defense Forces military personnel. AIDS Behav. 2013 Jun;17(5):1734-45.

2. David Parker R, Regier MD, Widmeyer J, Honaker J, Rüütel K. Reported contraceptive use, risk behaviours and STIs among military conscripts in Estonian defence forces. Int J STD AIDS. 2015 Oct;26(11):815-20.

3. Anastario MP, Dabreo J, Morris J, Hallum-Montes R, Arredondo G, Creel A, et al. Condom use following a pilot test of the Popular Opinion Leader intervention in the Barbados Defence Force. J Community Health. 2013 Feb;38(1):46-53.

4. Spaulding AB, Lifson AR, Iverson ER, Ganesan A, Landrum ML, Weintrob AC, et al.; Infectious Disease Clinical Research Program HIV Working Group. Gonorrhoea or chlamydia in a U.S. military HIV-positive cohort. Sex Transm Infect. 2012 Jun;88(4):266-71.
5. Brown AE, Ross DA, Simpson AJ, Erskine RS, Murphy G, Parry JV, Gill ON. Prevalence of markers for HIV, hepatitis B and hepatitis C infection in UK military recruits. Epidemiol Infect. 2011 Aug;139(8):1166-71.

6. Anastario M, Manzanero R, Blanco R, Reyes E, Jaramillo R, Black L, et al. HIV infection, sexual risk behaviour and condom use in the Belize defense force. Int J STD AIDS. 2011 Feb;22(2):73-9.

7. Singer DE, Bautista CT, O'Connell RJ, Sanders-Buell E, Agan BK, Kijak GH, et al. HIV infection among U.S. Army and Air Force military personnel: sociodemographic and genotyping analysis. AIDS Res Hum Retroviruses. 2010 Aug;26(8):889-94.

8. Samji H, Cescon A, Hogg RS, Modur SP, Althoff KN, Buchacz K, et al.; North American AIDS Cohort Collaboration on Research and Design (NA-ACCORD) of IeDEA. Closing the gap: increases in life expectancy among treated HIV-positive individuals in the United States and Canada. PLoS One. 2013 Dec 18;8(12):e81355. doi: 10.1371/journal. pone.0081355.

9. Gostin LO, Waxman HA, Foege W. The president's national security agenda: curtailing Ebola, safeguarding the future. JAMA. 2015 Jan 6;313(1):27-8

10. Mavedzenge SN, Luecke E, Ross DA. Effective approaches for programming to reduce adolescent vulnerability to HIV infection, HIV risk, and HIV-related morbidity and mortality: a systematic review of systematic reviews. J Acquir Immune Defic Syndr. 2014 Jul 1;66 Suppl 2:S154-69.

11. Broz D, Wejnert C, Pham HT, DiNenno E, Heffelfinger JD, Cribbin M, et al.; National HIV Behavioral Surveillance System Study Group. HIV infection and risk, prevention, and testing behaviors among injecting drug users - National HIV Behavioral Surveillance System, 20 U.S. cities, 2009. MMWR Surveill Summ. 2014 Jul 4;63(6):1-51.

12. Young SD, Szekeres G, Coates T. The relationship between online social networking and sexual risk behaviors among men who have sex with men (MSM). PLoS One. 2013 May 1;8(5):e62271. doi: 10.1371/journal. pone.0062271.

13. Freiman JM, Huang W, White LF, Geng EH, Hurt CB, Taylor LE, et al. Current practices of screening for incident hepatitis $\mathrm{C}$ virus $(\mathrm{HCV})$ infection among HIV-infected, HCV-uninfected individuals in primary care. Clin Infect Dis. 2014 Dec 15;59(12):1686-93.

14. de Waal A, Klot JF, Mahajan M. HIV/AIDS, security, and conflict: new realities, new responses: AIDS, Security, and Conflict Initiative. New York: SSRC; 2010.

15. Tekkel M, Veideman T. Health Behavior among Estonian Adult Population, 2014. Tallinn, Estonia: National Institute for Health Development; 2015.

16. Santos-Hövener C, Marcus U, Koschollek C, Oudini H, Wiebe M, Ouedraogo OI, et al. Determinants of HIV, viral hepatitis and STI prevention needs among African migrants in Germany; a cross-sectional survey on knowledge, attitudes, behaviors and practices. BMC Public Health. 2015 Aug 6;15:753. doi: 10.1186/s12889-015-2098-2.

17. Beltzer N, Saboni L, Sauvage C, Lydié N, Semaille C, Warszawski J; group KABP France. An 18-year follow-up of HIV knowledge, risk perception, and practices in young adults. AIDS. 2013 Mar 27;27(6):1011-9.

18. Parker RD, Regier M, Widmeyer J, Rüütel K. HIV/STI prevalence study among military conscripts in Estonia. J Community Health. 2015 Apr;40(2):271-5.

19. National Institute for Health Development. Finished Studies [Internet]. Tallinn: National Institute for Health Development; 2015 [cited 2015 May 10]. Available from: http://www.tai.ee/et/tegevused/teadustoo/loppenuduuringud. (In Estonian.)

20. Trummal A, Gluškova N, Murd M. HIV related knowledge, attitudes and behaviours among Estonian youth, 2010. Tallinn: National Institute for Health Development; 2011. (In Estonian.)

21. Chlamydia control in Europe. Stockholm: European Centre for Disease Prevention and Control; 2009.

22. Estonia's Kuperjanov battalion suffers from outbreak of norovirus. Postimees, Estonian News. 2013 Mar 3. 